Le Pichon, X., Bonnin, J. and Pautot, G., 1970. The Gibraltar end of the Azores-Gibraltar Plate boundary: an example of compressional tectonics (Abstract). Upper Mantle Committee Symposium. Flagstaff, Arizona, July, 1970.

Melson, W. G., Thompson, G. and van Andel, Tj. M., 1968. Volcanism and metamorphism in the Mid-Atlantic Ridge, $22^{\circ} \mathrm{N}$ latitude. J. Geophys. Res. 73, 5925.

Miyashiro, A., Shido, F. and Ewing, M., 1971. Metamorphism in the Mid-Atlantic Ridge near $24^{\circ}$ and $30^{\circ} \mathrm{N}$. In A discussion on the petrology of igneous and metamorphic rocks from the ocean floor. Bullard, E., Cann, J. R. and Matthews, D. H., (Eds.). Phil. Trans. Roy. Soc. London A, 268, 589.

Figure 2. Reverse print of a metabasalt (spilite) from a drill bit sample. The dark patches are porphyritic and glomeroporphyritic clusters of plagioclase accompanied by chlorite pseudomorphs set in a very fine-grained matrix of acicular feldspar, chlorite, and alteration products. Relic crystal outlines suggest that olivine, now replaced by chlorite, was originally present.

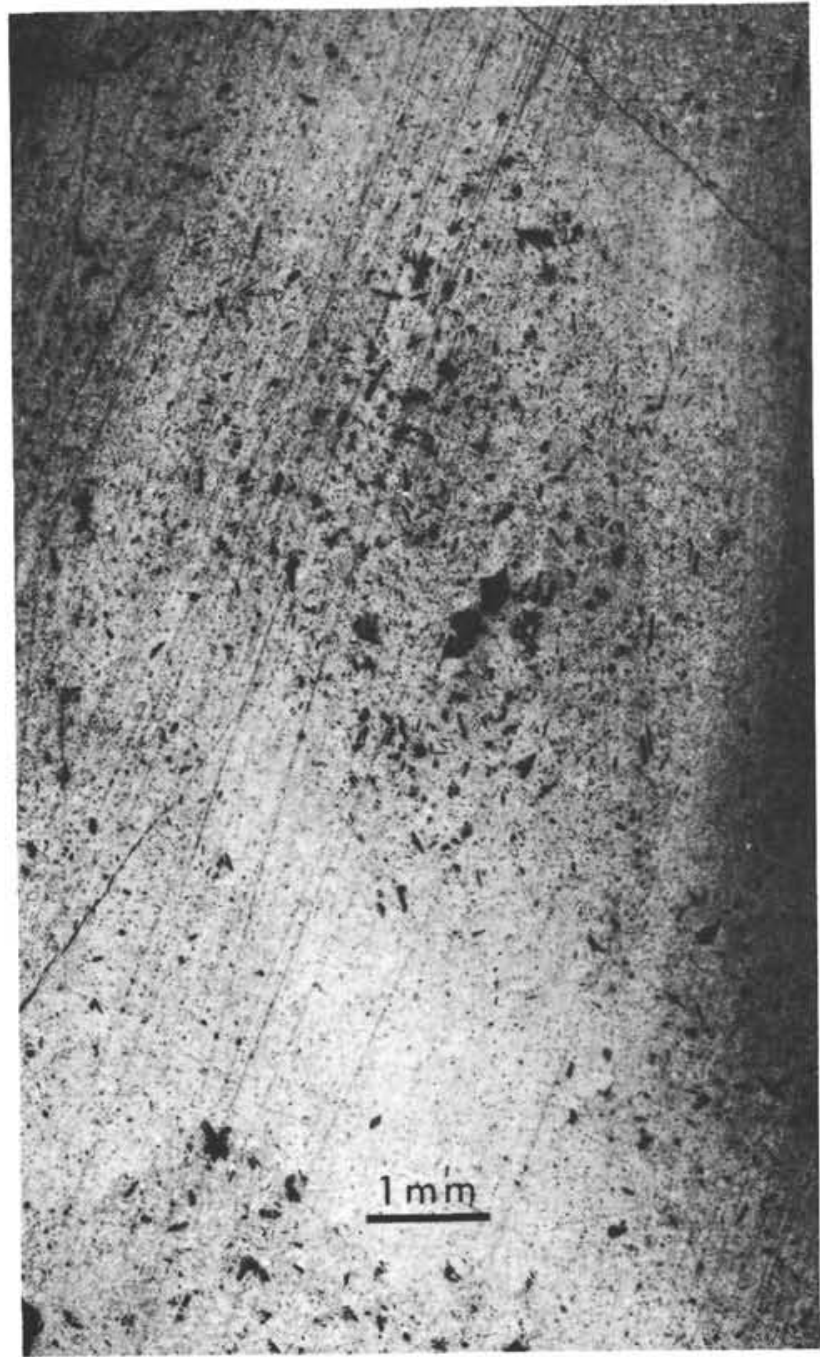

\title{
26.2. PETROGRAPHY OF ROCKS FROM THE CRESTAL AREA OF THE GORRINGE BANK
}

Anna T. Gavasci, Department of Geology and Geography, Hunter College of the City University of New York, New York Paul J. Fox, Department of Geological Sciences, State University of New York at Albany, Albany, New York and

William B. F. Ryan, Lamont-Doherty Geological Observatory of Columbia University, Palisades, New York

\section{INTRODUCTION}

Samples of igneous rock were recovered from the crestal area of Gorringe Bank in 1965 by coring and dredging from the R/V Robert D. Conrad of the Lamont-Doherty Geological Observatory. The sampling objective was to obtain materials which would shed light on the composition and geological history of this uplifted part of the AzoresGibraltar seismic zone. Numerous boulders and rock fragments were obtained in one dredge, RC 9-7 $\left(36^{\circ} 44.6^{\prime} \mathrm{N}\right.$, $11^{\circ} 05.8^{\prime} \mathrm{W}$; water depth $\left.=104-130 \mathrm{~m}\right)$, and two piston cores, RC 9-206 $\left(36^{\circ} 40.5^{\prime} \mathrm{N}, 11^{\circ} 04.4^{\prime} \mathrm{W}\right.$; water depth $=736$ $\mathrm{m})$ and $\mathrm{RC} 9-208\left(36^{\circ} 42^{\prime} \mathrm{N}, 11^{\circ} 07.3^{\prime} \mathrm{W}\right.$; water depth $=104$ $\mathrm{m})$.

Much of the recovered material was badly weathered, and most of the exposed rock faces were encrusted with carbonate crusts including colonies of byrozoa and coral. Smaller pebbles were often rounded, probably indicating abrasion near an ancient surf-zone on the bank.

Twenty samples were studied in thin section with a petrographic microscope. The analyses are presented in Tables 1 and 2 according to the two igneous rock suites recognized. 
TABLE 1

Oceanic Suite

\begin{tabular}{|c|c|c|c|}
\hline Sample & Rock Type & $\begin{array}{c}\text { Major } \\
\text { Mineral } \\
\text { Composition }\end{array}$ & $\begin{array}{c}\text { Metamorphic } \\
\text { Facies }\end{array}$ \\
\hline \multicolumn{4}{|c|}{ Oceanic Crustal Rocks } \\
\hline RC9-206-2 & Metagabbro & $\begin{array}{l}\text { Labradorite, } \\
\text { hornblende }\end{array}$ & Amphibolite \\
\hline RC9-206-3 & $\begin{array}{l}\text { Cataclastic } \\
\text { metagabbro }\end{array}$ & $\begin{array}{l}\text { Labradorite, } \\
\text { diallage, } \\
\text { iron oxides }\end{array}$ & $\begin{array}{l}\text { Greenschist } \\
\text { amphibolite }\end{array}$ \\
\hline RC9-206-5 & $\begin{array}{l}\text { Cataclastic } \\
\text { metagabbro }\end{array}$ & $\begin{array}{l}\text { Labradorite, } \\
\text { diallage, } \\
\text { apatite, iron } \\
\text { oxides }\end{array}$ & $\begin{array}{l}\text { Greenschist } \\
\text { amphibolite }\end{array}$ \\
\hline RC9-206-6 & $\begin{array}{l}\text { Cataclastic } \\
\text { metagabbro }\end{array}$ & $\begin{array}{l}\text { Labradorite, } \\
\text { diallage, } \\
\text { apatite, } \\
\text { iron oxides }\end{array}$ & $\begin{array}{l}\text { Greenschist } \\
\text { amphibolite }\end{array}$ \\
\hline RC9-206-11 & $\begin{array}{l}\text { Cataclastic } \\
\text { metagabbro }\end{array}$ & $\begin{array}{l}\text { Labradorite, } \\
\text { diallage, } \\
\text { apatite, } \\
\text { iron oxides }\end{array}$ & $\begin{array}{l}\text { Greenschist } \\
\text { amphibolite }\end{array}$ \\
\hline RC9-206-13 & $\begin{array}{l}\text { Cataclastic } \\
\text { metaanorthosite } \\
\text { (gabbro } \\
\text { fragment) }\end{array}$ & $\begin{array}{l}\text { Labradorite, } \\
\text { diallage }\end{array}$ & $\begin{array}{l}\text { Greenschist } \\
\text { amphibolite }\end{array}$ \\
\hline RC9-208-1 & $\begin{array}{l}\text { Cataclastic } \\
\text { metagabbro } \\
\text { (anorthosite) }\end{array}$ & Labradorite & Amphibolite \\
\hline \multicolumn{4}{|c|}{ Ultramafic (Mantle?) Rocks } \\
\hline RC9-206-12 & $\begin{array}{l}\text { Amphibole- } \\
\text { biotite pyroxene }\end{array}$ & $\begin{array}{l}\text { Augite, } \\
\text { aegerine-augite, } \\
\text { brown horn- } \\
\text { blende, biotite, } \\
\text { apatite, intersti- } \\
\text { tial zeolites }\end{array}$ & Amphibolite \\
\hline RC9-208-2502 & $\begin{array}{l}\text { Pyroxene bear- } \\
\text { ing hornblendite }\end{array}$ & $\begin{array}{l}\text { Brown horn- } \\
\text { blende, augite, } \\
\text { interstitial } \\
\text { apatite, sphene, } \\
\text { zeolite(?) }\end{array}$ & Amphibolite \\
\hline
\end{tabular}

\section{OCEANIC SUITE}

The first group of rocks (7 of 20 specimens) is characterized by cataclastic metagabbro which is composed of primary labradorite, diallage, and iron oxides with varying amounts of secondary amphibole (blue green hornblende, and/or actinolite), chlorite, and in some samples, quartz and epidote. Most of the metagabbro samples exhibit cataclastic textures. These metagabbro samples are similar to the metagabbro sample cored at Site 120 on the north flank of Gorringe Bank (described in Chapter 26.1) as well as the metagabbros recovered from the bounding walls of transform faults (see Miyashiro et al., 1971), and they are thought to compose the oceanic crust (Layer 3).

Two of the twenty samples are ultramafic specimens. One is an amphibole-biotite pyroxenite characterized by augite, aegirene-augite, brown hornblende, biotite, apatite, and interstitial zeolites. The other is a pyroxene-bearing hornblendite (Figure 1). The occurrence of actinolite and blue green hornblende, which mantle the primary brown
TABLE 2

Alkaline Suite ${ }^{\mathrm{a}}$

\begin{tabular}{|c|c|c|c|}
\hline Sample & Rock Type & $\begin{array}{c}\text { Major } \\
\text { Mineral } \\
\text { Composition }\end{array}$ & $\begin{array}{c}\text { Metamorphic } \\
\text { Facies }\end{array}$ \\
\hline \multicolumn{4}{|c|}{ Alkaline Intermediate Series } \\
\hline RC9-208-2 & $\begin{array}{l}\text { Aegirine } \\
\text { phonolite }\end{array}$ & $\begin{array}{l}\text { Aegirine, sani- } \\
\text { dine, nepheline, } \\
\text { analcite, iron } \\
\text { oxides }\end{array}$ & Zeolite \\
\hline RC9-208-4 & $\begin{array}{l}\text { Aegirine } \\
\text { phonolite }\end{array}$ & $\begin{array}{l}\text { Aegirine, sani- } \\
\text { dine, nepheline, } \\
\text { zeolites }\end{array}$ & Zeolite \\
\hline RC9-208-5 & $\begin{array}{l}\text { Sanidine } \\
\text { phonolite }\end{array}$ & $\begin{array}{l}\text { Sanidine, nephe- } \\
\text { line, aegirine, } \\
\text { nosean, iron } \\
\text { oxides, zeolites }\end{array}$ & Zeolite \\
\hline RC9-208-6 & $\begin{array}{l}\text { Nosean } \\
\text { phonolite }\end{array}$ & $\begin{array}{l}\text { Nosean(?), sani- } \\
\text { dine, nepheline, } \\
\text { aegirine, zeo- } \\
\text { lites, andesite }\end{array}$ & Zeolite \\
\hline RC9-208-8 & $\begin{array}{l}\text { Sanidine } \\
\text { phonolite }\end{array}$ & $\begin{array}{l}\text { Sanidine, } \\
\text { nepheline, } \\
\text { aegerine, anal- } \\
\text { cite, zeolites }\end{array}$ & Zeolite \\
\hline RC9-208-2504 & $\begin{array}{l}\text { Sanidine- } \\
\text { nosean } \\
\text { phonolite }\end{array}$ & $\begin{array}{l}\text { Sanidine, } \\
\text { nosean, nephe- } \\
\text { line, aegirine, } \\
\text { analcite(?), } \\
\text { zeolites }\end{array}$ & Zeolite \\
\hline \multicolumn{4}{|c|}{ Alkaline Mafic Series } \\
\hline RC9-208-3 & $\begin{array}{l}\text { Mafic } \\
\text { phonolite }\end{array}$ & $\begin{array}{l}\text { Sanidine, anal- } \\
\text { cite, nosean(?), } \\
\text { aegirine-augite, } \\
\text { aegirine, zeolites }\end{array}$ & Zeolite \\
\hline RC9-206-1 & $\begin{array}{l}\text { Mafic } \\
\text { phonolite }\end{array}$ & $\begin{array}{l}\text { Aegirine, sani- } \\
\text { dine, nepheline, } \\
\text { nosean, zeolite, } \\
\text { kaolinite }\end{array}$ & Zeolite \\
\hline RC9-208-250 1 & $\begin{array}{l}\text { Mafic } \\
\text { phonolite }\end{array}$ & $\begin{array}{l}\text { Nosean, aegir- } \\
\text { ine, nepheline, } \\
\text { sanidine, biotite, } \\
\text { anorthoclase }\end{array}$ & Zeolite \\
\hline $\mathrm{RC} 9-208-250_{3}$ & $\begin{array}{l}\text { Welded tuff } \\
\text { (or devitri- } \\
\text { fied lava) }\end{array}$ & $\begin{array}{l}\text { Nosean, horn- } \\
\text { blende, biotite, } \\
\text { pyroxene, leu- } \\
\text { cite(?), aegirine- } \\
\text { augite, aegirine, } \\
\text { sanidine, anorth- } \\
\text { clase, glassy } \\
\text { matrix }\end{array}$ & Zeolite \\
\hline RC9-206-7 & $\begin{array}{l}\text { Alkalic } \\
\text { metabasalt }\end{array}$ & $\begin{array}{l}\text { Altered olivine, } \\
\text { augite, plagio- } \\
\text { clase, inter- } \\
\text { stitial feld spa- } \\
\text { toid (nosean:), } \\
\text { melilite(?) }\end{array}$ & Zeolite \\
\hline
\end{tabular}

a $>10$ per cent feldspathoids.

hornblende and pyroxene, indicates amphibolite facies metamorphism; the occurrence of zeolite in veins and interstitial zeolite suggests later stage retrogressive zeolite metamorphism. Ultramafic rocks of this type have been recovered in dredge hauls from the base of transform fault escarpments (Dmitriev et al., 1971; Bonatti et al., 1971). The ultramafic rocks recovered from transform faults are interpreted as representing the lower part of oceanic crust or upper mantle(?). 


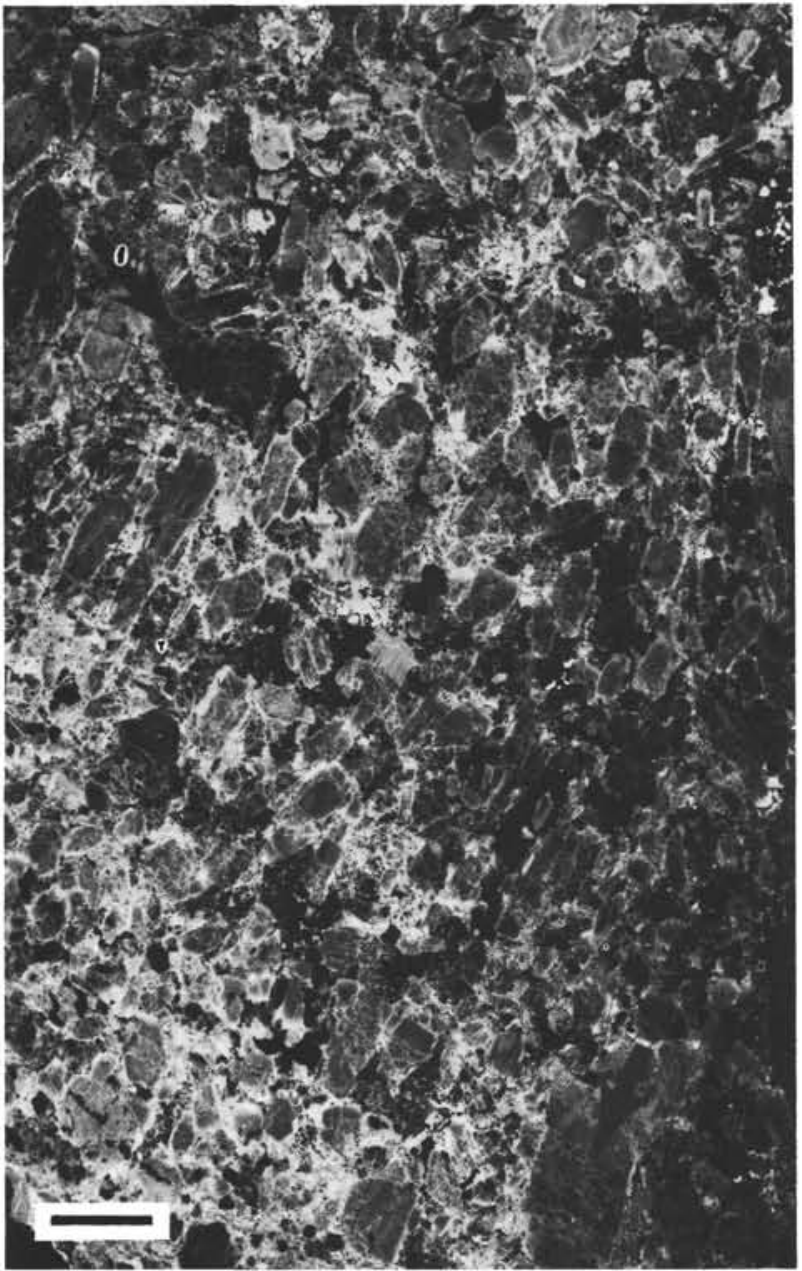

Figure 1. Reverse print enlargement of a thin section of pyroxene bearing hornblendite ( $R C$ 9-208-250 $)$; revealing a medium-grained fabric and brecciated appearance. The larger crystals (arrows) are brown amphibole of an edenite composition. Scale bar represents 1 millimeter.

\section{ALKALINE SUITE}

The second group of samples (11 of 20 specimens) is a suite of silica deficient, alkaline rocks (Figure 2) and is characterized by the occurrence of pyroxene (aegirine), feldspar (sanidine), and feldspathoids (nepheline and/or nosean) as the principal minerals and, depending on the sample, lesser amounts of analcite, hornblende, pyroxene (augite, or aegirine-augite), and iron oxides. The occurrence of zeolite in the matrix and in veins in all the samples suggests zeolite facies metamorphism. The occurrence of such undersaturated alkaline rocks in the cores and a dredge located on the crest of Gorringe Bank is unusual because this igneous rock type (phonolite) is not characteristic of the rock types typically recovered from the ocean floor (dredge hauls invariably recover one or a combination of the following rock types: tholeiitic basalt, alkaline basalt, metabasalt (zeolite and greenschist facies), gabbro, metagabbro (greenschist and amphibolite facies), and serpen-

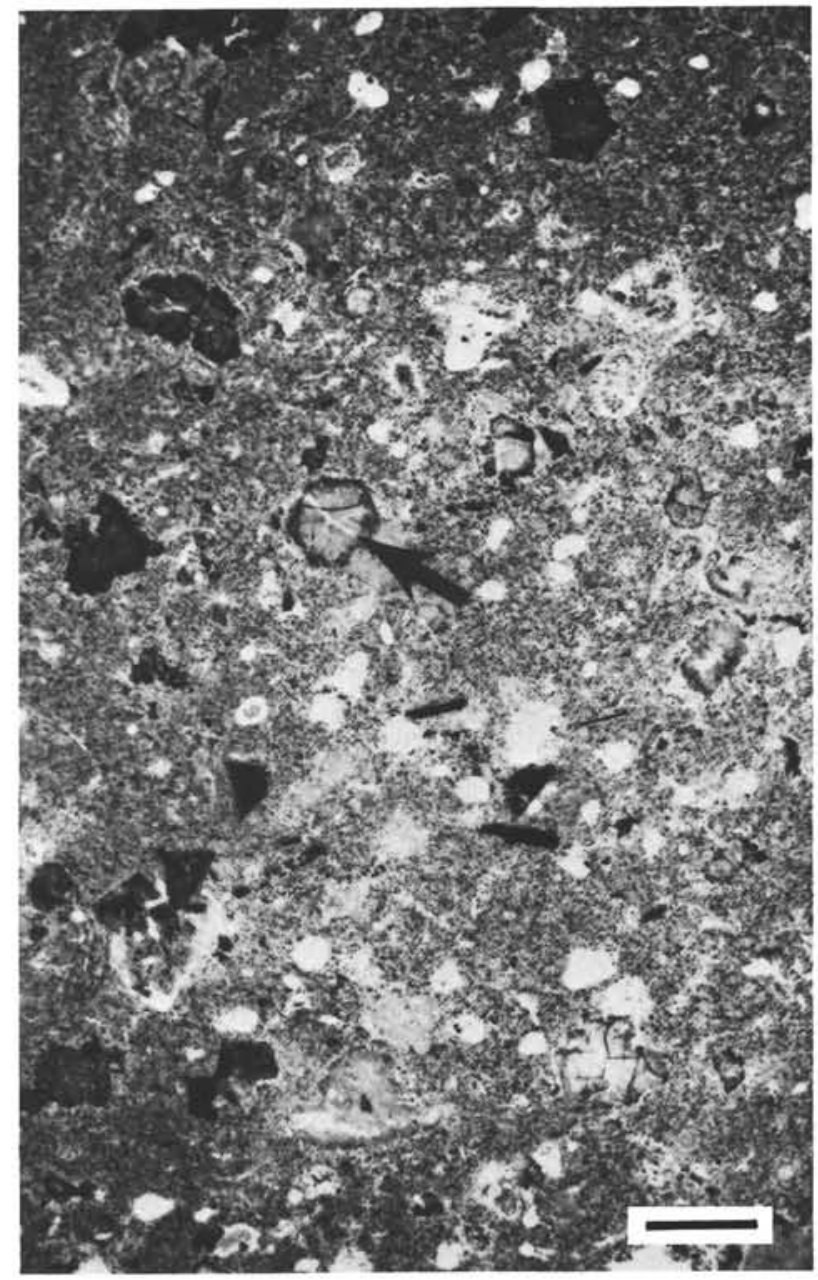

Figure 2. Reverse print enlargement of a thin section of mafic phonolite (RC 9-208-250 ), containing large crystals of nosean (arrow) and numerous thin laths of sanidine. Many of the more mafic minerals are replaced by dark green pyroxene and iron oxides. Biotite is also replaced and has inclusions of zircon without a pleocroic halo. Scale bar represents 1 millimeter.

tinized periodotite. Although phonolite rocks occur in minor amounts in a late stage differentiate in association with alkaline basalts on some volcanic oceanic islands (e.g., Ascension and St. Helena), phonolites are more generally found in association with igneous bodies located behind subducting zones (e.g., Andes).

The occurrence of metagabbros in bottom samples from the crest of Gorringe Bank, a part of the Azores-Gibraltar Ridge, is not surprising and in fact these rocks suggest that the oceanic crust (Layer 3 ) is exposed along a portion of Gorringe Bank. The occurrence of a suite of intermediate and mafic alkaline rocks composed of feldspathoids, however, is not similar to rocks previously sampled from the ocean basin, and this suite is certainly not compatible with the rock types thought to be generated along accreting plate margins of the Mid-Oceanic Ridge System. Rather, 
these feldspathoid rich rocks are characteristic of igneous rocks found behind some subducting margins. Although the feldspathoidal phonolites could represent later stage differentiates associated with an alkaline basalt seamount on the Azores-Gibraltar Ridge, we interpret the occurrence of the feldspathoidal phonolites as reflecting a short and rapid subducting phase which accompanied the deformation of the Horseshoe Abyssal Plain sediments and uplift of the Gorringe Bank. As to the age of the intrusions, we have noted welded tuffs containing xenoliths of mafic phonolite in direct association with baked skeletal debris of former neritic fauna. This evidence would place the intrusion of the phonolite at a time when the bank was already shallow. According to the facies sequence of pelagic sediment recovered at Site 120, the transition there from a deep oceanic sea bed commenced during or after the Early Miocene, and was essentially completed by the Early Pliocene.

\section{REFERENCES}

Bonatti, E., Honnorez, J. and Ferrera, G., 1971. Peridotitegabbro-basalt complex from the equatorial Mid-Atlantic Ridge. In A discussion on the petrology of igneous and metamorphic rocks from the ocean floor. Bullard, E., Cann, J. R., and Matthews, D. H., (Eds.). Phil. Trans. Roy. Soc. London A. 268, 385.

Dmitriev, L. V., Vinogradov, A.P. and Udintsev, G. B., 1971. Petrology of ultrabasic rocks from rift zones of the Mid-Indian Ocean Ridge. In A discussion on the petrology of igneous and metamorphic rocks from the ocean floor. Bullard, E., Cann, J. R. and Matthews, D. H. (Eds.). Phil. Trans. Roy. Soc. London A. 268, 403.

Miyashiro, A., Shido, F. and Ewing, M., 1971. Metamorphism in the Mid-Atlantic Ridge near $24^{\circ}$ and $30^{\circ} \mathrm{N}$. In A discussion on the petrology of igneous and metamorphic rocks from the ocean floor. Bullard, E., Cann, J. R., and Matthews, D. H., (Eds.). Phil. Trans. Roy. Soc. London, A. 268, 589. 